\title{
LATAR BELAKANG ASPEK KEHIDUPAN PADA SISTEM PENAMAAN JALAN DI KOTA YOGYAKARTA: KAJIAN ANTROPOLINGUISTIK
}

\author{
Prihadi dan Ari Listiyorini \\ Universitas Negeri Yogyakarta \\ email: prihadi.uny@gmail.com
}

\begin{abstract}
Abstrak
Penelitian mengenai onomastika telah beberapa kali dilakukan. Lewat penelitian onomastika dapat dijelaskan penggunaan aspek kebahasaan dan aspek lain seperti sejarah dan budaya, kehidupan, motivasi, serta alasan motivasi dan tujuan penamaan tersebut. Penelitian ini bertujuan untuk mendeskripsikan aspek kehidupan pada sistem penamaan jalan di Yogyakarta sebagai bagian dari keistimewaan Daerah Istimewa Yogyakarta. Penelitian ini menggunakan desain penelitian deskriptif. Penelitian dibatasi pada Kota Yogyakarta yang memiliki data nama jalan secara formal. Data berupa nama-nama jalan. Sumber data berupa sumber data tertulis dan lisan. Teknik pengumpulan data dengan observasi, wawancara, dan pencatatan. Analisis data dengan kultural-historis. Validasi dilakukan dengan triangulasi data dan metode. Penelitian menemukan 26 aspek kehidupan yang selanjutnya dapat dikelompokkan menjadi 9 aspek kehidupan. Aspek-aspek tersebut meliputi aspek tumbuhan dan binatang, aspek tempat (asal-usul tempat, fungsi tempat, penanda tempat, dan arah tempat), aspek yang berhubungan dengan keraton (kerabat keraton, prajurit keraton, tempat tinggal pegawai keraton, senjata perang), aspek geografis (ciri-ciri geografis, gunung/sungai, dan fenomena alam), aspek profesi, aspek pahlawan dan tokoh, aspek harapan dan cita-cita, aspek nama wayang, dan aspek lainnya (aktivitas kerja, karakter, dan sifat).
\end{abstract}

Kata kunci: nama jalan, aspek kehidupan, kultural-historis

\section{BACKGROUNDS OF THE LIFE ASPECTS ON THE ROAD NAMING SYSTEM IN YOGYAKARTA CITY: ANTHROPOLINGUISTIC STUDY}

\begin{abstract}
Research on onomastics has been conducted a number of times. Through onomastic research, road naming can be described in terms of the linguistic and other aspects such as history and culture, ways of life, and motives and objectives. This study is aimed at describing the aspects of life in the street naming system in Yogyakarta as part of the special features of the Yogyakarta Special Region. This study uses the descriptive research design. The research location in Yogyakarta is limited to the city of Yogyakarta which has formal road name data. Data are in the form of street names in the study location. Data sources are written and oral. Data
\end{abstract}


collection techniques are observation, interview, and recording. Data analysis is cultural-historical. Validation is done by data and method triangulations. Results show 26 aspects of life grouped into 9. These aspects are related to plants and animals, places (origin, function, marker, and direction), palaces (family kinship, soldier troop, official residence, and war weapon), geography (feature, mountain/river, and natural phenomena), profession, hero and figure, hope and ideal, wayang figure, and other (work activity, character, and nature).

Keywords: street names, aspects of life, cultural-historical aspect

\section{PENDAHULUAN}

Penelitian mengenai penamaan atau onomastika telah beberapa kali dilakukan. Sebagai contoh penelitian mengenai penamaan badan usaha seperti toko dan rumah makan (Riani, 2014; Wijana, 2014; Wahyono, 2009), penamaan orang/nama diri (Wibowo, 2001; Nurhayati, 2012; Widodo, 2013), dan penamaan tempat/toponimi (Sugianto, 2017). Berdasarkan penelitian onomastika tersebut selain dapat diketahui aspek linguistik (bentuk-bentuk bahasa) yang digunakan, juga dapat diketahui aspek-aspek lainnya, seperti aspek sejarah dan budaya, aspek kehidupan, motivasi dan tujuan, dan alasan motivasi dan tujuan penamaan tersebut. Hal tersebut dikarenakan bahasa tidak pernahlepas dari masyarakat pemakainya. Bahasa mempunyai hubungan yang sangat erat dengan budaya, yang berwujud gagasan, tingkah laku, dan hasil karya manusia tersebut. Bahasa dan budaya bagaikan keping mata uang yang selalu bersisihan di kedua sisinya. Perwujudan suatu bahasa sangat dipengaruhi oleh latar belakang sosial budaya masyarakat penutur bahasa tersebut (Mardikantoro, 2016).

Dari berbagai penelitian onomastika yang telah dilakukan tersebut terdapat satu kecenderung dalam memberikan nama-nama pada badan usaha yang masyarakat dirikan dan dalam penamaan diri, yaitu penggunaan bahasa asing dalam pemberian nama tersebut. Dalam penamaan badan usaha, bahasa Inggris mulai menggeser pemakaian bahasa Indonesia dan bahasa daerah. Beberapa alasan dikemukakan oleh pelaku usaha berkaitan dengan penggunaan bahasa Inggris tersebut. Sebagian besar menganggap penggunaan bahasa Inggris dipandang lebih modern dan prestisius. Pelaku usaha tersebut berpikir konsumen akan lebih tertarik dengan usaha mereka jika nama-nama yang digunakan menggunakan bahasa Inggris. Sementara itu, bahasa Arab mulai mendominasi penamaan diri. Dari penelitian yang telah dilakukan banyak orang tua yang menamakan anaknya dengan kata/ bahasa Arab untuk menunjukkan identitas keagaamaan mereka (muslim).

Kecenderungan menggunakan bahasa asing baik bahasa Inggris maupun bahasa Arab dalam penamaan agaknya tidak berlaku dalam penamaan yang berhubungan dengan tempat geografi/toponimi ataupun nama jalan. Dari penelitian yang telah dilakukan mengenai desa atau 
dusun, tidak ada satu pun yang menggunakan bahasa asing dalam namanama desa/ dusun tersebut. Begitu juga dengan observasi awal yang telah dilakukan mengenai nama jalan. Jalan biasanya dinamai dengan aspek yang berhubungan dengan nama-nama tokoh masyarakat yang berjasa pada waktu itu ataupun dengan kondisi geografis daerah tersebut. Selain kedua aspek tersebut, masih banyak aspek kehidupan lain yang dijadikan sumber penamaan jalan di suatu masyarakat. Dari pengamatan tersebut tidak ada nama jalan yang menggunakan bahasa Inggris ataupun bahasa asing lainnya.

Begitu juga observasi awal mengenai nama jalan yang ada di Yogyakarta. Penamaan jalan-jalan yang ada di Yogyakarta dapat menunjukkan berbagai macam aspek, baik aspek linguistik, aspek kehidupan, aspek kesejarahan, maupun aspek sosial budaya yang tidak lepas dari keistimewaan Daerah Istimewa Yogyakarta. Sebagai contoh Jalan Batikan, Jalan Kemasan, dan Jalan Jlagran. Penamaan ketiga jalan tersebut berhubungan dengan pekerjaan masyarakat yang mendiami wilayah tersebut, yaitu sebagai pembuat batik, pengrajin emas, dan pembuat jlogro atau nisan. Lalu ada Jalan Affandi yang menunjukkan tokoh budaya di Yogyakarta.

Selain berbagai aspek yang melatarbelakangi munculnya penamaan jalan, juga dapat dilihat motivasi dan tujuan, serta alasan motivasi dan tujuan penamaan jalan di Yogyakarta. Namanama jalan tersebut dapat digunakan untuk melihat masyarakat Yogyakarta dari berbagai sisi dengan segala keunikannya dan keistimewaannya. Sebagaimana tercantum dalam UndangUndang Republik Indonesia Nomor 13 Tahun 2012 tentang Keistimewaan Daerah Istimewa Yogyakarta tentang kebudayaan. Dalam bab IX pasal 31 ayat 1 disebutkan bahwa kewenangan kebudayaan diselenggarakan untuk memelihara dan mengembangkan hasil cipta, rasa, karsa, dan karya, yang berupa nilai-nilai pengetahuan, norma, adat istiadat, benda, seni, dan tradisi luhur yang mengakar dalam masyarakat DIY. Penamaan jalan di Yogyakarta inilah sebagai salah satu cara untuk memelihara dan mengembangkan budaya tersebut.

Berkaitan dengan keistimewaan Daerah Istimewa Yogyakarta ada suatu peristiwa yang berhubungan dengan nama jalan, yaitu penggantian beberapa ruas nama jalan di Yogyakarta, pada tahun 2013. Penggantian nama ruas jalan yang dikembalikan ke nama aslinya tersebut bertujuan untuk menghidupkan filosofi asli nama jalan tersebut. Namanama jalan yang dikembalikan sesuai aslinya sebagai contoh misalnya Jalan Trikora dikembalikan ke Jalan Pangurakan, Jalan Ahmad Yani kembali menjadi Jalan Margomulyo, dan Jalan pangeran Mangkubumi menjadi Jalan Margoutomo. Penelitian mengenai penamaan jalan di Yogyakarta tentunya menarik untuk dicermati, diteliti, untuk mengetahui bagaimana situasi sejarah sosio kultural masyarakat Yogyakarta sebagai propinsi yang menyandang status istimewa ini dibalik nama-nama jalan yang ada di Yogyakarta. Dengan penelitian ini diharapkan masyarakat Yogyakarta, baik generasi saat ini maupun generasi berikutnya mengetahui 
tentang aspek linguistik, aspek kehidupan, sejarah, dan situasi sosio kultural masyarakat Yogyakarta secara keseluruhan. Dari berbagai aspek yang melatarbelakangi munculnya penamaan jalan di Yogyakarta, penelitian ini bertujuan untuk mendeskripsikan aspek kehidupan pada sistem penamaan jalan di Yogyakarta sebagai bagian dari keistimewaan Daerah Istimewa Yogyakarta. Penelitian ini menggunakan desain penelitian deskriptif.

\section{METODE}

Penelitian ini menggunakan desain penelitian deskriptif kualitatif. Dalam penelitian deskriptif ini dideskripsikan aspek-aspek kehidupan yang melatarbelakangi penamaan jalan di Yogyakarta sebagai bagian dari keistimewaan Daerah Istimewa Yogyakarta (DIY). Penelitian deskriptif bertujuan untuk mendeskripsikan gambaran ciri-ciri data secara akurat sesuai dengan sifat alamiah data itu sendiri (Djajasudarma, 2006:16).

Kota Yogyakarta dipilih sebagai lokasi penelitian dikarenakan hanya Kota Yogyakarta yang memiliki arsip data nama jalan. Empat kabupaten lainnya, yaitu Kabupaten Sleman, Kabupaten Bantul, Kabupaten Kulonprogo, dan Kabupaten Gunungkidul tidak memiliki arsip nama jalan. Seandainya ada arsip tentang nama jalan, hanya berisi nama-nama ruas jalan, seperti yang ada di Kabupaten Sleman. Sebenarnya, di setiap ruas jalan terdapat papan yang menunjukkan nama jalan tersebut. Akan tetapi, untuk keotentikan data, akhirnya hanya Kota Yogyakarta sajalah yang dijadikan lokasi dalam penelitian ini.
Data dalam penelitian ini adalah nama-nama jalan yang ada di Yogyakarta, khususnya di Kota Yogyakarta. Sumber data tertulis dan sumber data lisan menjadi sumber data dalam penelitian ini. Sumber data tertulis diperoleh dari arsip Dinas Perhubungan dan Bina Marga Kota Yogyakarta mengenai namanama jalan, kamus, ensiklopedi, bukubuku folklore, sejarah, dan budaya. Sementara itu, sumber data lisan berasal dari pemerhati budaya dan pustakawan serta pakar ahli budaya.

Pada dasarnya peneliti sendiri (human instrument) yang menjadi instrumen dalam penelitian ini. Teknik wawancara, teknik baca, dan teknik catat sebagai teknik pengumpulan data. Teknik wawancara dilakukan untuk mengumpulkan informasi dari narasumber. Sementara itu, teknik baca dan catat juga dilakukan untuk mengumpulkan informasi mengenai nama jalan yang berasal dari arsip pemerintah daerah Kota Yogyakarta dan dari dokumen tertulis lainnya. Dari penyediaan data tersebut, kemudian dilakukan pengidentifikasian data dan selanjutnya dilakukan pemilahan untuk membuat klasifikasi data.

Teknik historis kultural digunakan sebagai teknik analisis data dalam penelitian ini. Teknik historis kultural yang alat penentunya di dalam bahasa yang bersangkutan digunakan untuk menganalisis aspek kehidupan dari nama-nama jalan yang ada di Yogyakarta.

Validitas atau pemeriksaan keabsahan data dilakukan dengan teknik triangulasi data dan triangulasi metode. Dalam triangulasi data dilakukan pengumpulan data dari berbagai sumber data, yaitu 
dari pengamatan secara langsung, dari dokumentasi, dan dari narasumber. Sementara itu, triangulasi metode dilakukan dengan menggunakan berbagai macam metode dalam penelitian ini, yaitu metode kultural-historis, observasi langsung, wawancara, dan pencatatan.

\section{HASIL DAN PEMBAHASAN Hasil}

Dari hasil penelitian yang telah dilakukan dapat ditemukan beberapa aspek kehidupan yang melatarbelakangi penamaan jalan di Kota Yogyakarta. Ada 26 aspek, tetapi dalam Tabel 1 dikelompokkan menjadi 9 aspek saja.

Berdasarkan Tabel 1, dapat diketahui aspek-aspek yang melatarbelakangi munculnya nama-nama jalan di wilayah Kota Yogyakarta. Nama yang dijadikan subjek penelitian ada 130 nama jalan. Nama-nama jalan tersebut bersumber dari aspek kehidupan masyarakat Yogyakarta sebagai pemiliknya. Sumber aspek kehidupan kehidupan masyarakat Yogyakarta yang menjadi inspirasi penamaan jalan dapat dikategorikan ke dalam sembilan kategori aspek kehidupan.

\section{Pembahasan}

Pembahasan akan diurutkan sesuai dengan frekuensi penggunaanya sebagai berikut.

\section{Aspek Tumbuhan dan Binatang}

Penamaan jalan yang bersumber pada aspek kehidupan dunia tumbuhan dan binatang contohnya adalah Jalan Tegal Lempuyangan, Jalan Kapas I, Jalan
Polowijan, Jalan Cendana, Jalan Menjangan, Jalan Sukonandi, Jalan Gagak Rimang, Jalan Modang, dan lain sebagainya. Melihat banyak data nama jalan di Kota Yogyakarta yang bersumber dari nama tumbuhan dan nama binatang dapat dipahami bahwa masyarakat pemilik atau pemberi nama jalan tersebut mempunyai budaya kehidupan yang dekat atau lekat dengan dunia tumbuhan dan dunia binatang.

Jalan Tegal lempuyangan, Jalan Kapas I, Jalan Polowijan, dan Jalan Cendana adalah nama-nama jalan yang dilatarbelakangi oleh aspek tumbuhan. Dunia tumbuhan atau pohon menjadi sumber kehidupan masyarakat Yogyakarta, menjadi bagian yang penting dalam hidup mereka, memberikan inspirasi dan motivasi pada kehidupan mereka, memberikan harapan hidup dan menenteramkan hidup mereka. Jalan Tegal Lempuyangan berhubungan dengan tumbuhan/ tanaman lempuyang. Tumbuhan ini merupakan salah satu dari rempah-rempah yang banyak digunakan dalam masyarakat Jawa. Rempahrempah yang banyak ditanam oleh masyarakat Jawa selain lempuyang, misalnya cengkeh, kemiri, kayu manis, jahe, lengkuas, kapulaga, pala, kunyit, kencur, dan lain sebagainya. Selain sebagai bumbu dapur atau bahan masakan, rempah-rempah termasuk lempuyang ini banyak digunakan sebagai obat dan bahan baku obat herbal (http:// bppp.kemendag.go.id). Jalan Kapas berhubungan dengan kapas (kapuk), tumbuhan yang banyak tumbuh di masyarakat Jawa. Kapas dapat digunakan sebagai bahan isi kasur (walaupun saat 
Tabel 1. Aspek Kehidupan dalam Penamaan Jalan di Kota Yogyakarta

\begin{tabular}{|c|c|c|c|}
\hline No. & Aspek Kehidupan & Frekuensi & Contoh Nama Jalan \\
\hline 1. & Aspek tumbuhan dan binatang & $21,7 \%$ & $\begin{array}{l}\text { Jalan Tegal Lempuyangan, } \\
\text { Jalan Kapas I, Jalan Polowijan, } \\
\text { Jalan Cendana, Jalan Menjangan, } \\
\text { Jalan Sukonandi, } \\
\text { Jalan Gagak Rimang, } \\
\text { Jalan Modang }\end{array}$ \\
\hline 2. & $\begin{array}{l}\text { Aspek tempat (asal-usul tempat, } \\
\text { fungsi tempat, penanda tempat, } \\
\text { dan arah tempat) }\end{array}$ & $19,7 \%$ & $\begin{array}{l}\text { Jalan Lowanu, Jalan Ngeksigondo, } \\
\text { Jalan Kricak, Jalan Kleben, } \\
\text { Jalan Panti Panaungan, } \\
\text { Jalan Tegal Gendu, } \\
\text { Jalan Pangurakan, } \\
\text { Jalan Magangan Kulon }\end{array}$ \\
\hline 3. & $\begin{array}{l}\text { Aspek yang berhubungan dengan } \\
\text { keraton } \\
\text { (kerabat keraton, prajurit keraton, } \\
\text { tempat tinggal pegawai keraton, } \\
\text { senjata perang) }\end{array}$ & $14,5 \%$ & $\begin{array}{l}\text { Jalan Mantrigawen Lor, } \\
\text { Jalan Madyosuro, } \\
\text { Jalan Patang Puluhan, } \\
\text { Jalan Sultan Agung, } \\
\text { Jalan P. Benawa, } \\
\text { Jalan Nyi pembayun, } \\
\text { Jalan Suryomentaraman }\end{array}$ \\
\hline 4. & $\begin{array}{l}\text { Aspek geografis (ciri-ciri } \\
\text { geografis, } \\
\text { gunung/ sungai, dan fenomena } \\
\text { alam) }\end{array}$ & $9,9 \%$ & $\begin{array}{l}\text { Jalan Jetis Pasiraman, } \\
\text { Jalan Semanu, } \\
\text { Jalan Mendung Warih, Jalan Prau, } \\
\text { Jalan Kali Sahak, } \\
\text { Jalan Kemitbumen, } \\
\text { Jalan Gowongan Kidul }\end{array}$ \\
\hline 5. & Aspek Profesi & $9,9 \%$ & $\begin{array}{l}\text { Jalan Klitren, Jalan Pandeyan, } \\
\text { Jalan Patehan Tengah, } \\
\text { Jalan Kemasan }\end{array}$ \\
\hline 6. & Aspek pahlawan dan tokoh & $7,5 \%$ & $\begin{array}{l}\text { Jalan Jendral Sudirman, } \\
\text { Jalan I Dewa Nyoman Oka, } \\
\text { Jalan Prof. Dr. Herman Yohanes, } \\
\text { Jalan Kiai Gunomerico }\end{array}$ \\
\hline 7. & Aspek harapan/cita-cita & $6,9 \%$ & $\begin{array}{l}\text { Jalan Lobaningratan, Jalan Gejayan, } \\
\text { Jalan Tohpati, Jalan Pamularsih, } \\
\text { Jalan Madubronto }\end{array}$ \\
\hline 8. & Aspek nama wayang & $6,9 \%$ & $\begin{array}{l}\text { Jalan Abimanyu, } \\
\text { Jalan Bimosakti, } \\
\text { Jalan Permadi, } \\
\text { Jalan Pandu }\end{array}$ \\
\hline 9. & $\begin{array}{l}\text { Aspek lainnya (aktivitas kerja, } \\
\text { karakter/ } \\
\text { sifat) }\end{array}$ & $3 \%$ & Jalan Landung, Jalan Nitikan \\
\hline
\end{tabular}

114 | LITERA, Volume 19, Nomor 1, Maret 2020 
ini banyak yang menggunakan springbed), bahan pembuatan benang, bahan utama membuat kain, perban dan plester luka, cotton bud, bahan kecantikan, dan juga sebagai komoditi ekspor.

Jalan polowijan berhubungan dengan palawija, tanaman selain tanaman pokok yang dimanfaatkan untuk memenuhi kebutuhan pokok. Yang termasuk tanaman palawija, yaitu jagung, kentang, ubi, singkong, kacang panjang, wortel dan lain sebagainya. Masyarakat Yogyakarta pada umumnya memanfaatkan tanaman padi sebagai bahan makanan pokok. Namun, ada kalanya mereka juga menanam dan memanfaatkan tanaman palawija ketika musim kering tiba. Palawija ini juga sering ditanam di beberapa daerah yang tidak bisa tumbuh padi dengan baik. Selanjutnya, Jalan cendana, atau juga sering disebut dengan kayu wangi. Kayunya yang wangi dimanfaatkan sebagai bahan pembuat perabot rumah tangga. Sementara itu, bagian pohon lainnya dapat diimanfaatkan sebagai minyak herbal untuk mengatasi berbagai macam keluhan seperti pusing, imsomnia, masalah kulit, aroma terapi, bahan dupa, dan campuran parfum.

Apabila dihubungkan dengan penelitian penamaan di belahan dunia barat, penamaan jalan di Kota Yogyakarta yang bersumber pada tumbuhan merupakan temuan yang penting dalam penelitian ini karena cermin bahwa pola pikir masyarakat Kota Yogyakarta dekat sekali dengan dunia tanaman/tumbuhan. Hal itu sesuai dengan fakta bahwa bidang mata pencaharian penduduk di Propinsi Daerah Istimewa Yogyakarta zaman dahulu dipengaruhi oleh tipe daerahnya.
Di daerah Kota Yogyakarta, atau Kabupaten Sleman, Bantul, Gunungkidul, dan Kulon Progo zaman dahulu sebagian besar penduduk bermata pencarian di bidang pertanian, perikanan, dan peternakan, di samping ada sebagian kecil sebagai pegawai atau karyawan, yang dikenal sebagai masyarakat agraris.

Sementara itu, penamaan jalan yang bersumber dari nama hewan/binatang biasanya binatang piaraan, sebagai contoh Jalan Menjangan, Jalan Sukonandi, Jalan Gagak Rimang, Jalan Modang. Jadi tidak sembarang nama hewan/binatang. Binatang piaraan tentu binatang yang menghadirkan kesenangan atau keuntungan atau binatang yang dianggap mulia atau bertuah dalam pandangan masyarakat. Sebagai contoh Menjangan: binatang yang lincah, Gagak rimang: burung yang gagah perkasa, dan Modang: burung yang berbulu warna kuning dan kicauannya indah.

\section{Aspek Tempat (asal-usul tempat, fungsi tempat, penanda tempat, dan arah tempat)}

Penamaan jalan ini bersumber dari aspek asal-usul tempat sebagai contoh yaitu Jalan Lowanu, Jalan Ngeksigondo, Jalan Kleben, dan Jalan Kricak. Jalan Lowanu menunjuk pada fakta bahwa para pejuang yang berperang di wilayah TKP adalah prajurit Pangeran Diponegoro yang datang dari Lowanu, Daerah Purworejo, sedangkan Jalan Ngeksigondo itu menunjuk pada fakta bahwa Pangeran Sutowijoyo (Raja Mataram Islam), ngeksi berarti mata, gondo berarti bau harum, jadi digabung menjadi matarum nama sandi dari Mataram. Jalan Kleben dikarenakan daerah tersebut merupakan dataran 
rendah/ daerah yang rendah dan sering kebanjiran. Jalan Kricak itu menunjuk pada fakta bahwa di daerah tersebut banyak batu kerikil (kricak).

Penamaan jalan yang bersumber pada aspek fungsi tempat, seperti: Jalan Panti Panaungan, Jalan Tegalgendu, Jalan Pangurakan, dan Jalan Magangan Kulon. Jalan Panti Panaungan menunjuk pada tempat berlindung, yaitu di tempat tersebut ada pondok pesantren yang dapat dijadikan untuk hidup nyaman lepas dari ajaran buruk, Jalan Tegalgendu menunjuk pada fakta bahwa tempat tersebut cocok untuk tempat pertemuan yang santai dan akrab, yaitu ada tanah perbukitan dan taman di tepi Sungai Gajah Wong. Jalan Pangurakan menunjuk pada fakta bahwa di tempat itu digunakan untuk mengikat kuda para tamu keraton, dan Jalan Magangan Kulon menunjuk pada fakta bahwa tempat itu digunakan untuk menyimpan gamelan keraton, yakni Kyai Guntur madu dan Nogowilogo.

Penamaan yang bersumber pada arah tujuan, seperti: Jalan Magelang, Jalan Batikan, dan Jalan Gading. Jalan Magelang menuju ke arah Kota Magelang, Jalan Batikan menuju ke tempat pekerja batik, dan Jalan Gading menuju ke tempat kandang gajah. Jalan Gading yang menuju kandang Gajah ini berada di Alun-Alun Kidul/ selatan. Di sebelah barat alun-alun kidul ini terdapat Gajah yang merupakan lambang kebijaksanaan. Binatang sebagai simbol sangat lekat dengan kehidupan masyarakat Jawa. Dengan lambang ini diharapkan Sultan dapat bijaksana dalam memutuskan sesuatu. Dahulu, gajah di kandang selalu ada. Namun, sejak akhir tahun 2009, dua gajah yang terdapat di kandang gajah tersebut dititipkan di Kebun Binatang Gembira Loka dikarenakan perawatan dan pemeliharaan yang menyedot biaya (https://regional. kompas.com).

\section{Aspek yang Berhubungan dengan Keraton (kerabat keraton, prajurit keraton, tempat tinggal pegawai keraton, senjata perang)}

Ada beberapa nama jalan di Kota Yogyakarta yang dilatarbelakangi oleh aspek yang berhubungan dengan Keraton, seperti Jalan Mantrigawen Lor, Jalan Madyosuro, Jalan Patang Puluhan, Jalan Sultan Agung, Jalan P. Benawa, Jalan Nyi Pembayun, dan Jalan Suryomentaraman.

Penamaan jalan di lingkungan Kota Yogyakarta dilihat dari aspek kehidupan ada yang mendasarkan diri pada fakta sejarah keberadaan Keraton Yogyakarta dan dengan pola pikir kehidupan budaya Keraton Yogyakarta, yaitu penamaan jalan bersumber pada peristiwa sejarah keberadaan Keraton Yogyakarta dengan segala seluk-beluknya, seperti: tempat tinggal kerabat keraton, pejabat keraton, nama diri kerabat keraton, prajurit keraton, pegawai keraton, dan simbolsimbol kekuasaan keraton baik yang berupa bagian dari bangunan keraton maupun prasasti. Salah satunya adalah nama diri kerabat keraton. Penamaan jalan di Kota Yogyakarta yang bersumber pada nama diri kerabat keraton, antara lain: Jalan Sultan Agung, Jalan P. Benawa, Jalan Nyi Pembayun, Jalan Suryomentaraman, dan lain-lain.

Jalan Sultan Agung berkaitan dengan Raja Kerajaan Mataram yang merupakan kerajaan terbesar di Jawa dan nusantara 
pada masa itu. Sementara itu, Jalan P. Benawa berkaitan dengan Pangeran Benawa. Pangeran Benawa adalah Putra Hadiwijaya atau Jaka Tingkir yang merupakan raja pertama Pajang. Pangeran Benawa adalah raja ketiga Kesultanan Pajang yang bergelar Sultan Prabuwijaya. Dalam sejarahnya disebutkan bahwa Pangeran Benawa adalah figur putra raja yang tulus ikhlas. Dia memilih untuk menjadi seorang pertapa saja dengan melepas tahtanya kepada kakak angkatnya, Danang Sutawijaya atau Panembahan Senopati (putra Ki Ageng Pemanahan). Jalan Nyi Pembayun berkaitan dengan Pembayun, anak dari Sutawijaya yang bersuamikan Ki Ageng Mangir. Ki Ageng Mangir merupakan musuh dan sekaligus juga sebagai menantu Panembahan Senapati/ Raden Sutawijaya, raja Kerajaan Mataram yang pertama. Yang terakhir yaitu jalan Suryamentaram. Suryamentaram, yang bernama kecil Raden Mas Kudiarmadji, adalah anak ke-55 Hamengkubuwana VII dengan Raden Ayu Retnomandojo (salah satu selir raja, putri Patih Danureja VI). Walaupun sebagai seorang anak raja, tetapi Suryamentaram memutuskan untuk menjadi rakyat jelata, dan menjadi seorang ahli kebudayaan dan filsuf. Beliau mengembangkan ajaran kawruh jiwa yang dapat digunakan dalam psikoterapi, hal yang fundamental dalam psikologi (Kholik, A., \& Himam, 2015).

Aspek kehidupan keraton/kerajaan adalah bagian yang penting dalam kehidupan masyarakat ini. Data hasil penelitian ini sesuai dengan hipotesis Saphir dan Whorf (Sampson, 1980) bahwa budaya akan mempengaruhi bahasa. Lebih lanjut hipotesis mereka berbunyi bahwa bahasa membentuk persepsi manusia terhadap realitas dunia luar. Sebaliknya, bisa dinyatakan bahwa bagaimana suatu masyarakat memandang realitas dunia luar dapat dilihat dari bahasanya. Senada dengan pendapat tersebut, Wierzbicka (1992) menyatakan bahwa bahasa mencerminkan konseptualisasi manusia, penafsiran manusia terhadap dunia.

Di sisi lain, bahasa adalah cermin pikiran dan pengalaman manusia yang sempurna. Pernyataan tersebut sesuai dengan teori bahwa bahasa merupakan lambang yang sempurna dari pengalaman manusia, bahasa tidak dapat dipisahkan dari tindakan, dan bahasa merupakan wahana ungkapan yang nuansanya sangat halus (Bright, 1947: 66). Di sinilah letak kerangka hubungan antara pikiran dan bahasa.

Penamaan jalan yang bersumber pada nama prajurit keraton, sebagai contoh: Jalan Madyasuro, Jalan Matrigawen, dan Jalam Siliran Lor. Jalan Madyosuro menunjuk pada fakta ada kelompok pegawai keraton (abdi dalem) yang disebut pegawai madyosuro; pegawai yang mengurusi gamelan, prajurit mantrigawen: mengurusi para pekerja di keraton, dan prajurit siliran: pegawai yang mengontrol penerangan di keraton.

\section{Aspek Geografis (ciri-ciri geografis, gunung/sungai, dan fenomena alam)}

Latar belakang penamaan jalan ada yang bersumber dari aspek geografi. Penamaan jalan yang bersumber pada aspek geografi juga menonjol dalam banyak penamaan, bukan hanya nama jalan saja, tetapi juga pada toponimi suatu tempat. Dalam hal nama jalan 
dapat dicontohkan seperti: Jalan Jetis Pasiraman, Jalan Semanu, Jalan Mendung Warih, dan sebagainya. Jetis itu menunjuk wilayah yang terletak di sudut, sedangkan pasiraman menunjuk air terjun (grojogan:Jw.), Semanu sama dengan semangu yang artinya air terjun, mendung warih menunjuk awan yang tebal sehingga akan turun hujan.

Terdapat juga penamaan jalan yang bersumber pada penyebutan gunung dan sungai yang masuk ke dalam kategori aspek geografi, sebagai contoh penamaan jalan: Prau, Kali Sahak, Celeban, dan Kemit Bumen. Nama-nama jalan yang bersumber pada gunung dan sungai itu terdapat di wilayah Kota Baru Yogyakarta sebelum nama-nama jalan tersebut diubah menjadi nama-nama pahlawan atau pejuang. Jalan Kali sahak, Jalan Prau itu merupakan nama jalan di sekitar Masjid Suhada, sedangkan Jalan Celeban dan Jalan Kemit Bumen berada di wilayah Glagahsari. Rupa-rupanya Jalan Kali Sahak menunjuk pada keberadaan sungai yaitu Sungai Code yang melambangkan kehidupan yang makmur, sedangkan Jalan Prau menunjuk pada fakta bahwa zaman dahulu untuk menyeberang Sungai Code perlu naik prau. Jalan Celeban menunjuk pada fakta lokasi ini dilewati aliran Sungai Gajah Wong sehingga sering terendam bila banjir karena topografinya tanah rendah, sedangkan Jalan Kemit Bumen menunjuk fakta bahwa jalan ini sangat sempit.

\section{Aspek Profesi}

Urutan selanjutnya penggunaan nama jalan yang dilatarbelakangi oleh aspek profesi, seperti: Jalan Klitren, Jalan
Pandeyan, Jalan Patehan Tengah, dan Jalan Kemasan. Nama-nama jalan tersebut berturut-turut menunjuk pada profesi kuli kereta api, pembuat barang dari besi (pande), pembuat teh (di keraton), dan pembuat emas. Namanama jalan yang bersumber pada profesi seperti disebutkan di depan memang cukup banyak digunakan, yaitu ada 9,9\%. Hal ini membuktikan bahwa aspek kehidupan profesi termasuk bagian yang penting dalam kehidupan masyarakat Yogyakarta khususnya masyarakat Kota Yogyakarta. Bisa juga dinyatakan masyarakat Yogyakarta menghormati hadirnya profesi tersebut dalam kehidupannya.

\section{Aspek Pahlawan dan Tokoh}

Penamaan jalan ada yang bersumber pada nama-nama pahlawan/pejuang. Tentu sudah pasti dengan penamaan jalan dengan nama pahlawan/pejuang itu merupakan bentuk cara menghormati dan mengenang jasa mereka. Contoh nama jalan dari nama pahlawan/pejuang itu seperti: Jalan Jendral Sudirman, Jalan I Dewa Nyoman Oka, Jalan Prof. Dr. Ir. Herman Yohanes, dan lain-lain. Jenderal Sudirman merupakan pahlawan Indonesia yang gigih berjuang dan bergerilya bersama para parajuritnya melawan tentara Belanda pada agresi militer II walaupun dalam keadaan sakit. Beliau merupakan Panglima Besar Tentara Nasional Republik Indonesia. Selain itu, Jenderal Sudirman juga merupakan pahlawan kemerdekaan nasional (Ayuningtyas, dkk., 2017:11). Pada akhir hayatnya, beliau dimakamkan di Tamam Makam Pahlawan Kusuma 
Negara Yogyakarta. Sementara itu, I Dewa Nyoman Oka adalah seorang pejuang yang berasal dari Bali yang gugur pada tahun 1945, pada serangan umum ke markas Jepang. Prof. Dr, Herman Yohanes ialah tokoh yang pernah menjadi Rektor UGM, digunakan sebagai nama jalan karena untuk mengenang sekaligus menuju ke UGM karena beliau juga merupakan mantan rektor UGM.

Penamaan jalan ada juga yang bersumber pada nama tokoh ulama, seperti Jalan Kyai Gunomerico. Jalan Kyai Gunomerico menyebut salah satu kyai yang mengasuh di pondok pesantren di daerah tersebut.

\section{Aspek Harapan dan Cita-cita}

Penamaan jalan yang bersumber pada harapan/cita-cita akan mampu memberikan inspirasi pada anggota masyarakat bagaimana jalan hidup ini, hidup akan dibawa ke mana, apa yang harus dilakukan untuk sampai ke sana. Tentu harapan/citacita yang terkandung di dalam nama jalan merupakan harapan/cita-cita mulia sehingga mampu menuntun kehidupan manusia ke arah kehidupan yang mulia. Sebagai contoh jalan yang dilatarbelakangi oleh aspek harapan/cita-cita, yaitu Jalan Lobaningratan, Jalan Gejayan, Jalan Pamularsih, Jalan Madubronto, dan sebagainya. Lobaningratan berarti harapan untuk dapat hidup dengan baik, gejayan berasal dari kejayan yang berarti harapan supaya jaya atau berhasil menakhlukkan atau mengalahkan sesuatu, pamularsih mengasihi sesama, madubronto berarti berjuang untuk mendapatkan kesuksesan.

\section{Aspek Nama Wayang}

Penamaan jalan yang bersumber pada aspek kehidupan wayang atau harapan/ cita-cita menandakan bahwa kesenian wayang merupakan kesenian yang ada di hati dan pikiran masyarakat Yogyakarta. Kesenian wayang adalah kesenian yang populer di kalangan masyarakat Jawa. Kesenian ini, pada masyarakat Jawa, tumbuh dan berkembang serta diwariskan secara turun-temurun (Nurgiyantoro, 2011:18).

Di samping sebagai hiburan, wayang juga mengandung banyak nilai-nilai luhur yang terkandung di dalamnya, antara lain nilai pendidikan, nilai moral, nilai kepemimpinan dan keteladanan, perilaku baik buruk, juga ilmu supranatural. Sebagai hiburan wayang menyajikan banyak menyampaikan berbagai nilai seni, seperti jalan cerita/ alur yang menggambarkan proses kehidupan itu sendiri, seni pedalangan, seni nyinden, dan seni kerawitan. Dewasa ini, warisan budaya tradisional ini telah menjadi milik bangsa Indonesia, tidak hanya milik masyarakat etnik tertentu saja (Nurgiyantoro, 2016).

Sebagai contoh nama tokoh wayang yang digunakan dalam penamaan jalan di Kota Yogyakarta, yaitu Abimanyu, Yomodipati, Bimosakti, Permadi, Pandu, dan sebagainya. Tokoh-tokoh wayang yang dipilih sebagai penamaan jalan tersebut pada umumnya mempunyai watak dan karakter yang baik dan kuat. Sebagai contoh Permadi yang merupakan nama lain dari Arjuna. Arjuna dalam wayang digambarkan sebagai tokoh yang mempunyai watak yang halus, baik tingkah lakunya dan pemberani. Sementara itu, Abimanyu merupakan 
putra Arjuna yang gugur di medan peperangan di Kurusetra. Pandu adalah ayah dari Arjuna, seorang satria yang gemar berkelana, bertapa, dan suka menuntut ilmu. Bima dan Yomodipati digambarkan sebagai tokoh yang kuat dan keras.

\section{Aspek Lainnya (Aktivitas kerja, dan karakter manusia)}

Penamaan jalan yang bersumber pada aktivitas kerja, seperti: Jalan Nitikan dan Jalan Dongkelan. Jalan Nitikan menunjuk pada aktivitas orang sedang membatik dan Jalan Dongkelan menunjuk pada aktivitas orang mengerjakan kebun tebu.

Penamaan jalan yang bersumber pada karakter manusia, seperti: Jalan Sidikan dan Jalan Landung. Jalan Sidikan menunjuk pada karakter manusia yang jujur dan Jalan Landung menunjuk pada karakter manusia yang sabar.

\section{Pola Pikir Masyarakat Yogyakarta yang Berhubungan dengan Aspek-Aspek Yang Melatarbelakangi Penamaan Jalan di Kota Yogyakarta}

Dari uraian aspek-aspek yang melatarbelakangi penamaan jalan di Kota Yogyakarta di atas dapat dijelaskan bahwa pola berpikir atau wawasan masyarakat Yogyakarta dalam membuat nama-nama jalan termasuk masyarakat yang berwawasan luas. Cakupan aspek kehidupan yang dijadikan dasar pembuatan nama jalan banyak dan beragam/bervariasi. Fakta tersebut dapat dintepretasikan secara historis-kultural (antropologis) bahwa pola berpikir masyarakat Kota Yogyakarta dalam membentuk nama jalan berada pada tahap tataran kompleks karena bahasa adalah cermin pikiran (Thomas, L., \& Wareing, S., 1999). Oleh karena aspek kehidupan yang melatarbelakangi penamaan jalan di Kota Yogyakarta cukup variatif maka dari fakta ini dapat dinyatakan bahwa aktivitas memberi/ membuat nama jalan merupakan cermin pikiran yang lebih kompleks dan luas.

Ditegaskan dalam penelitian "Sistem Nama diri dalam Masyarakat Jawa" oleh Suharno (1987) dinyatakan ada 5 (lima) macam, antara lain, penanda jati diri, cita-cita, harapan, pemujaan tokoh, dan kepercayaan. Demikian pula dalam penelitian Sumarsih (1981) yang mengklasifikasikan fungsi penamaan yakni untuk mengenang tokoh dan atas dasar profesi.

Hal ini diperkuat oleh pendapat Frans Magnis Suseno bahwa sistem penamaan (Onomastika) dapat bersumber pada tiga kaidah dasar hidup. Tiga kaidah dasar yang dimaksud adalah prinsip kerukunan/kekerabatan, rasa hormat, dan etika keselarasan sosial (Suseno,1991). Lebih lanjut penamaan jalan dapat bersumber pada pandangan hidup masyarakat. Suseno (1991) menyatakan pandangan hidup adalah keyakinan deskriptif tentang realitas sejauh merupakan suatu kesatuan daripadanya manusia memberi suatu struktur yang bermakna kepada alam pengalamannya. Pandangan hidup merupakan kerangka acuan bagi manusia untuk dapat mengerti masing-masing unsur pengalamannya. Pandangan hidup Jawa merupakan realitas yang tidak terpisah satu sama lain, tetapi realitas sebagai satu kesatuan yang menyeluruh. Lebih lanjut dinyatakan bahwa pandangan hidup bukanlah pengertian yang abstrak, 
melainkan berfungsi sebagai sarana untuk berhasil mengatasi masalahmasalah kehidupan. Nilai pragmatis pandangan. Hidup orang Jawa untuk mencapai keadaan psikis tertentu adalah ketenangan, ketentraman, dan keseimbangan batin.

Pada sisi yang lain, dari hasil penelitian ini, nama jalan yang menunjuk pada nama diri kerabat keraton merupakan temuan dalam penelitian ini dan membedakan dengan penelitian nama-nama jalan sebelumnya di dalam maupun di luar negeri. Hasil temuan tersebut akan dapat mengukuhkan bahwa permasalahan hubungan kekerabatan di keraton atau pada masyarakat umumnya, bangsa Indonesia, merupakan bagian yang penting, khususnya dalam kehidupan masyarakat Yogyakarta dan umumnya masyarakat Indonesia.

Untuk mengakhiri pembahasan tentang penamaan jalan, dengan tetap berpegang pada prinsip pokok bahwa bahasa sebagai sistem representasi pola pikir, pola perilaku, dan pola budaya masyarakat, akan dapat dikukuhkan kebenaran paradigma Sapir-Whorf, yakni tentang hubungan antara bahasa dengan budaya, atau sebaliknya. Jadi, studi antropolinguistik adalah kajian interdisipliner antara bahasa dan budaya atau sebaliknya (Foley, 1997; Duranti, 1997).

Bahasa terikat oleh konteks budaya. Dengan ungkapan yang lain, bahasa dapat dipandang sebagai perluasan budaya. Berdasarkan hipotesis SapirWhorf, sebenarnya setiap bahasa menunjukkan dunia simbolik yang khas, yang melukiskan realitas pikiran, pengalaman batin, dan kebutuhan penuturnya. Bahasa dapatmempengaruhi penuturnya dalam berpikir, melihat lingkungan dan alam sekitarnya sehingga untuk sampai menemukan konteks hasil budaya, seperti penamaan jalan atau sejarah penamaan jalan. Persitiwa tersebut perlu dirunut melalui kesimpulan bahwa tanpa bahasa kita tidak dapat berpikir, bahasa mempengaruhi persepsi, dan bahasa mempengaruhi pola berpikir (Thomas, L. dan Wareing, S., 1999:32).

Karakteristik yang penting terkait dengan penamaan jalan Kota Yogyakarta adalah kehidupan masyarakat yang didasarkan pada adanya pemerintahan kerajaan. Fakta sejarah membuktikan bahwa pada abad 16, di Kecamatan Kotagede berdiri sebuah kerajaan, bernama Mataram Kuno/Hindu dengan raja Ki Pemanahan. Dalam sejarah Kerajaan Mataram inilah di kemudian hari akan menjadi cikal-bakal berdirinya kerajaan Ngayogyakarta Hadiningrat dengan raja Sultan Agung yang bergelar Sultan Hamengku Bowono I (HB I) dan sampai sekarang Sultan Hamengku Buwono X. Kehidupan kerajaan ini pasti merupakan faktor yang sangat penting dan faktor yang mewarnai segi-segi kehidupan masyarakat Yogyakarta.

\section{SIMPULAN}

Dari uraian yang telah dipaparkan dapat disimpulkan bahwa terdapat banyak aspek kehidupan dalam masyarakat Yogyakarta yang melatarbelakangi penamaan jalan di Kota Yogyakarta. Aspek-aspek dalam penamaan jalan ini sangat variatif. Hal ini terbukti dari ditemukannya 26 aspek kehidupan yang dapat dikelompokkan menjadi 9 aspek kehidupan, dari aspek 
tumbuhan dan binatang, aspek kehidupan dan kerabat karaton, sampai dengan aspek harapan dan cita-cita. Semua aspek dalam penamaan jalan ini menggambarkan kehidupan masyarakat Yogyakarta dari zaman dahulu ataupun saat ini yang masih relevan dengan kehidupan sehari-hari.

\section{UCAPAN TERIMA KASIH}

Artikel ini adalah bagian dari hasil penelitian unggulan yang dibiayai dengan dana DIPA UNY tahun 2018. Ungkapan terima kasih dicurahkan kepada Rektor Universitas Negeri Yogyakarta yang telah memberi kesempatan untuk melakukan penelitian ini. Selain itu, terima kasih kepada narasumber yang telah berkenan memberikan informasi terkait dengan penelitian ini.

\section{DAFTAR PUSTAKA}

Ayuningtyas, D. R., Suharso, R., \& Sodiq, I. (2016). Perjuangan Panglima Besar Jenderal Soedirman pada Masa Revolusi Fisik Tahun 1945-1950. Journal of Indonesian History, 5(1), 10-17, https://journal. unnes.ac.id/sju/index.php/jih/ article/view/19720.

Bright, B. (1947). Studi es in Linguistics Relativity in Headings in Social Psychology, E.E. Maccoby, dkk. (ed.). New York: Hold Rinehart and Winston.

Djajasudarma, T.F. (2006). Metode Linguistik Ancangan Metode Penelitian dan Kajian. Bandung: PT. Eresco.

Duranti, A. (1997). Linguistic Anthropology. Cambridge: Cambridge University Press.
Foley, W.A. (1997). Anthropological Linguistics. Massachusetts: Blackwell Publisher Inc.

https://regional.kompas.com / $\mathrm{read} / 2010 / 02 / 24 / 14172840 /$ Gajah.Keraton.Simbol.yang. Hilang?page=all. "Gajah Keraton, Simbol yang Hilang”.

Kementerian Perdagangan Republik Indonesia, Badan Pengkajian dan Pengembangan Perdagangan. (2017). Potensi Ekspor Rempahrempah Indonesia http://bppp. kemendag.go.id/ media content/2017/08/ Leaflet- Potensi_ Ekspor_Rempah-Rempah_ Indonesia.pdf).

Kholik, A dan Himam. F. (2015). Konsep Psikoterapi Kawruh Jiwa Ki Ageng Suryomentaram. Gadjah Mada Journal of Psychology, 1(2), 120-134. https://jurnal.ugm.ac.id/gamajop/ article/view/ 7349/5726.

Mardikantoro, H.B.(2016). Pemertahanan Bahasa Jawa dalam Pertunjukan Kesenian Tradisional di Jawa Tengah. Jurnal Litera:Jurnal Penelitian Bahasa, Sastra, dan Pengajarannya, Volume 15, Nomor 2, Oktober 2016. https://journal.uny. ac.id/index.php/litera/article/ view/11828/8471

Nurgiyantoro, B. (2011). Wayang dan Pengembangan Karakter Bangsa. Jurnal Pendidikan Karakter, 1(1), 1834. https://journal.uny.ac.id/index. php/jpka/article/view/1314/1092. (2016). Transformasi Cerita Wayang dalam Novel Amba dan Pulang. Jurnal Litera:Jurnal Penelitian Bahasa, Sastra, dan Pengajarannya, Volume 15, Nomor 2, 
Oktober 2016. https://journal.uny. ac.id/index.php/litera/article/ view/11823/8466

Nurhayati. (2012). From Marto to Marfelino: A Shift in Naming in Gotputuk Village. Makalah pada prosiding Seminar International Language Maintenance and Shift (LAMAS) II. ISSN: 2088-6799, . 254-59. http://eprints.undip.ac.id/54066/1/ Proceedings_International_Seminar July_5-6_2012_no_scure_-_Andi_ Rizki_Fauzi.pdf.

Riani. (2014). Dominasi Bahasa Inggris pada Papan Nama Badan Usaha di Yogyakarta. Widyaparwa 42(2), 141152.DOI: https://doi.org/10.26499/ wdprw.v42i2.92.

Sampson, G. (1980). School of Linguistics. London: Hutchinson.

Sugianto, A. (2017). Pola Nama Desa di Kabupaten Ponorogo pada Era Adipati Raden Batoro Katong. Jurnal Sosio Humaniora, 2017, 10(1), hal https://iptek.its.ac.id/index. $\mathrm{php} / \mathrm{jsh} /$ article/view/2300.

Suharno. (1987). Sistem Nama Diri dalam Masyarakat Jawa. Laporan Penelitian. Yogyakarta: Proyek Pembinaan Bahasa \& Sastra Indonesia dan Daerah DIY.

Sumarsih, S. (1981). Asal-Usul Nama Kampung yang Ada Hubungannya dengan Kraton Kasunanan Yogyakarta. Patra Widya, Nomor 33:43-140. Yogyakarta: Jaranitra.
Suseno, F.M. (1991). Etika Jawa; Sebuah Analisa Falsafi Tentang Kebijaksanaan Hidup Jawa. Jakarta: PT. Gramedia Pustaka Utama.

Thomas, L. \& Wareing, S. (1999). Language, Society, and Power. New York: Routledge.

Wahyono, H. (2009). Bahasa Asing dalam Teks Papan Nama Usaha di Magelang. Jurnal Penelitian Inovasi, 32(2), 115-84. https://media.neliti. $\mathrm{com} / \mathrm{media} /$ publications/17871ID-bahasa-asing-dalam-teks-papannama-usaha-dimagelang.pdf.

Wibowo, R. M. (2001). Nama diri etnik Jawa. Jurnal Humaniora, 12(1), 45-55. https://jurnal.ugm.ac.id/ jurnalhumaniora/ article/view/710/556.

Widodo, S.T. (2013). Konstruksi Nama Orang Jawa: Studi Kasus NamaNama Modern di Surakarta. Jurnal Humaniora 25(1), 82-91. https:// jurnal.ugm.ac.id/jurnal-humaniora/ article/view/ 1815/1633.

Wijana, I. D. P. (2014). Bahasa, Kekuasaan, dan Resistensinya: Studi tentang Nama-Nama Badan Usaha di Daerah Istimewa Yogyakarta. Jurnal Humaniora, 26(1), 56-64. https://jurnal.ugm.ac.id/jurnal$\mathrm{h} \mathrm{u} \mathrm{m} \mathrm{a} \mathrm{n} \mathrm{i} \mathrm{o} \mathrm{r} \mathrm{a} \mathrm{/} \mathrm{a} \mathrm{r} \mathrm{t} \mathrm{c} 1$ e / view/4700/4115.

Wierzbicka, A. (1992). Semantic, Cognition, and Culture. London: Oxford University Press. 